\section{Article}

SANGOI, L. ${ }^{1 *}$ (D)

DURLI, M.M. ${ }^{1} \mathbb{D}$

SOUZA, C.A. ${ }^{1}$ (D)

LEOLATO, L.S. ${ }^{1}$ (D)

KUNESKI, H.F. ${ }^{1} \mathbb{D}$

COELHO, A.E. ${ }^{1}$ (D)

\title{
MaIze Response to TrineXapaC-Ethyl and Nitrogen FERTILIZATION
}

\author{
Resposta do Milho a Trinexapac-Ethyl e Adubação Nitrogenada
}

ABSTRACT - High nitrogen rates favor maize vegetative growth and grain yield losses due to stem lodging. The use of growth regulators can mitigate such effect. This work was carried out aiming to evaluate the effect of trinexapac ethyl on maize hybrids response to side-dress nitrogen rates. The experiment was carried out in Lages, Santa Catarina State, South of Brazil, during two growing seasons with two hybrids (P1680 and P30F53), and four nitrogen rates $\left(0,150,300\right.$ and $\left.450 \mathrm{~kg} \mathrm{~N} \mathrm{ha}^{-1}\right)$ were tested, with and without the presence of trinexapac ethyl. The experimental design was in randomized blocks arranged in split-split plots, with three replications per treatment. The plants height and ear insertion height, plant lodging and breaking, grain yield and yield components were evaluated. Grain yield increased in a quadratic way with increased nitrogen rate. The highest grain yields were 15,784 and $15,257 \mathrm{~kg} \mathrm{ha}^{-1}$, in 2014/15 and 2015/16, respectively. Application rates higher than $150 \mathrm{~kg}$ of $\mathrm{N} \mathrm{ha}^{-1}$, regardless of the use of the plant growth regulator, promoted maximum grain yield increases, ranging from 14.7 to $18.1 \%$. The application of trinexapac-ethyl reduced the upper stem internode length, 1000-grain dry weight and did not affect the percentage of lodged plants and grain yield of both hybrids. Therefore, the use of trinexapac-ethyl did not enhance the maize grain yield response to increased rates of side-dress nitrogen.

Keywords: Zea mays, side-dress nitrogen, productivity.

RESUMO - Altas doses de nitrogênio favorecem o crescimento vegetativo do milho e a perda no rendimento de grãos devido ao acamamento de plantas. Este efeito pode ser mitigado pelos reguladores de crescimento. Objetivou-se com este estudo avaliar o efeito do regulador de crescimento trinexapac-ethyl na resposta de híbridos de milho as doses de nitrogênio em cobertura. O experimento foi conduzido em Lages, SC, em dois anos agrícolas, testando dois híbridos (P1630 e P30F53) e

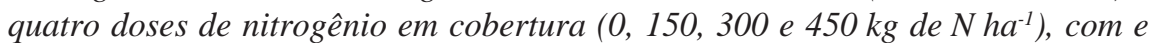
sem o uso de trinexapac-ethyl. O delineamento experimental foi em blocos casualizados dispostos em parcelas sub-subdivididas, com três repetições por tratamento. Avaliaram-se a altura de plantas e inserção de espiga, o acamamento e quebra de plantas, o rendimento de grãos e os componentes do rendimento. $O$ rendimento de grãos aumentou de forma quadrática com o incremento das doses de nitrogênio. Os máximos rendimentos de grãos foram de 15.784 e $15.257 \mathrm{~kg} \mathrm{ha}^{-1}$, em 2014/2015 e 2015/2016, respectivamente. Doses maiores do que $150 \mathrm{~kg} \mathrm{ha}^{-1}$ de $N$, independentemente da utilização do regulador de crescimento, promoveram, no máximo, incrementos no rendimento de grãos de 14,7\% a 18,1\%. A aplicação de trinexapac-ethyl reduziu o comprimento dos entrenós superiores do colmo e a massa de mil grãos, mas não interferiu na porcentagem de plantas acamadas e no rendimento de grãos. Portanto, o uso de trinexapac-ethyl não aumenta a resposta do rendimento de grãos do milho ao incremento na dose de nitrogênio em cobertura.

Palavras-chave: Zea mays, cobertura, produtividade.

${ }^{1}$ Universidade do Estado de Santa Catarina (UDESC), Lages-SC, Brasil. 


\section{INTRODUCTION}

Nitrogen is the most required mineral nutrient by maize crops and the one that most increases grain yields when properly applied (Scherer, 2012; Vargas et al., 2015). For each ton of grains produced, the plants need to take up nearly $28 \mathrm{~kg}$ of $\mathrm{N}$ from the soil (Goes et al., 2013). However, soils are not able to provide all $\mathrm{N}$ required by the crop due to its chemical instability in the environment, requiring application of only a small amount of $\mathrm{N}$ at sowing and high rates as a side-dress to make up the shortfall and meet the crop needs at times of greater demand (Mundstock and Silva, 2005).

Maize response to nitrogen fertilization depends on the amount of $\mathrm{N}$ available in soil, time of application and rates as well as the plant characteristics (Santos et al., 2011). There is also a distinct response of maize genotypes to nitrogen fertilization (Fagherazzi et al., 2016). Nitrogen fertilization must be well managed to achieve optimum efficiency of use, considering the growing concerns about nitrate pollution in the environment, especially in water bodies, due to improper management of nitrogen fertilization (Duete et al., 2008). In addition, to achieve high yields, high nitrogen application rates and high plants density in crops are used. However, high nitrogen rates may cause excessive vegetative growth of the plant and impair roots production, resulting in more disease-susceptible leaves and plant lodging and breaking. These effects cause crop yield losses (Sangoi et al., 2016).

An alternative to allowing application of high $\mathrm{N}$ rates, thus mitigating lodging and stems breaking, is the use of growth regulators. These products are synthetic substances that act on plant metabolism, affecting the beginning and modification of development of organs and tissues (Kappes et al., 2011). Among the growth regulators used in crops, trinexapac-ethyl is one of the most common. It acts by inhibiting the biosynthesis of gibberellins, reducing the stem length and, consequently, plant height. Application of trinexapac-ethyl modulates wheat plants architecture and enhances the plant efficiency in taking up nitrogen and other nutrients used in the crop to obtain high yields (Penckowski et al., 2010; Chavarria et al., 2015).

In maize crops, different rates and different times of application of the growth regulator trinexapac-ethyl resulted in increased leaves width and reduced leaves length, but did not have an effect on grains yield (Zagonel and Ferreira, 2013). However, in another study conducted in Brazil, it was found a decrease in grains yield per plant using trinexapac-ethyl (Pricinotto et al., 2015). Application of other growth regulator, ethephon diethyl aminoethyl hexanoate (EDAH), provided an $8 \%$ increase in grains yield (Zhang et al., 2014). This shows diverging results with the use of growth regulators in maize crops.

Application of the growth regulator trinexapac-ethyl may allow to use high nitrogen doses, maximizing the crop production potential without losses caused by plants lodging or stems breaking. The achievement of higher yields as a result of the association between the growth regulator and high $\mathrm{N}$ rates applied as side-dress can be a management strategy to raise the efficiency of nitrogen uptake by maize.

This study was conducted with the aim of assessing the influence of use of the growth regulator trinexapac-ethyl on the maize hybrids response to the application of different side-dress nitrogen rates.

\section{MATERIAL AND METHODS}

This study consisted of a field experiment conducted in 2014/15 and 2015/16 growing seasons, in the municipality of Lages, SC. The geographic coordinates of the experimental area are $27^{\circ} 50^{\prime} 35^{\prime \prime} \mathrm{S}$ and $50^{\circ} 29^{\prime} 45^{\prime \prime} \mathrm{W}$, and altitude of 849 meters. The soil of the experimental area is classified as Typic Dystrophic Red Nitotsol (Embrapa, 2006). Analysis of soil fertility at the 0-20 cm

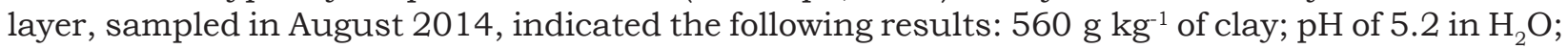
Shoemaker, Mac Lean \& Pratt (SMP) index of $5.7 ; 60 \mathrm{~g} \mathrm{~kg}^{-1}$ of organic matter; $4.4 \mathrm{mg} \mathrm{dm}^{-3}$ of P; $186 \mathrm{mg} \mathrm{dm}^{-3}$ of $\mathrm{K} ; 5.79 \mathrm{cmol}_{\mathrm{c}} \mathrm{dm}^{-3}$ of $\mathrm{Ca} ; 2.47 \mathrm{cmol}_{\mathrm{c}} \mathrm{dm}^{-3}$ of $\mathrm{Mg} ; 0.1 \mathrm{cmol}_{\mathrm{c}} \mathrm{dm}^{-3}$ of $\mathrm{Al}$; and $8.94 \mathrm{cmol}_{\mathrm{c}} \mathrm{dm}^{-3}$ of CEC. During the experiments, the meteorological data indicated $824 \mathrm{~mm}$ of accumulated rainfall and $18.8{ }^{\circ} \mathrm{C}$ of mean temperature at the first growing season, and $994 \mathrm{~mm}$ of accumulated rainfall and $19.4{ }^{\circ} \mathrm{C}$ of mean temperature at the second growing season (Figure 1). 

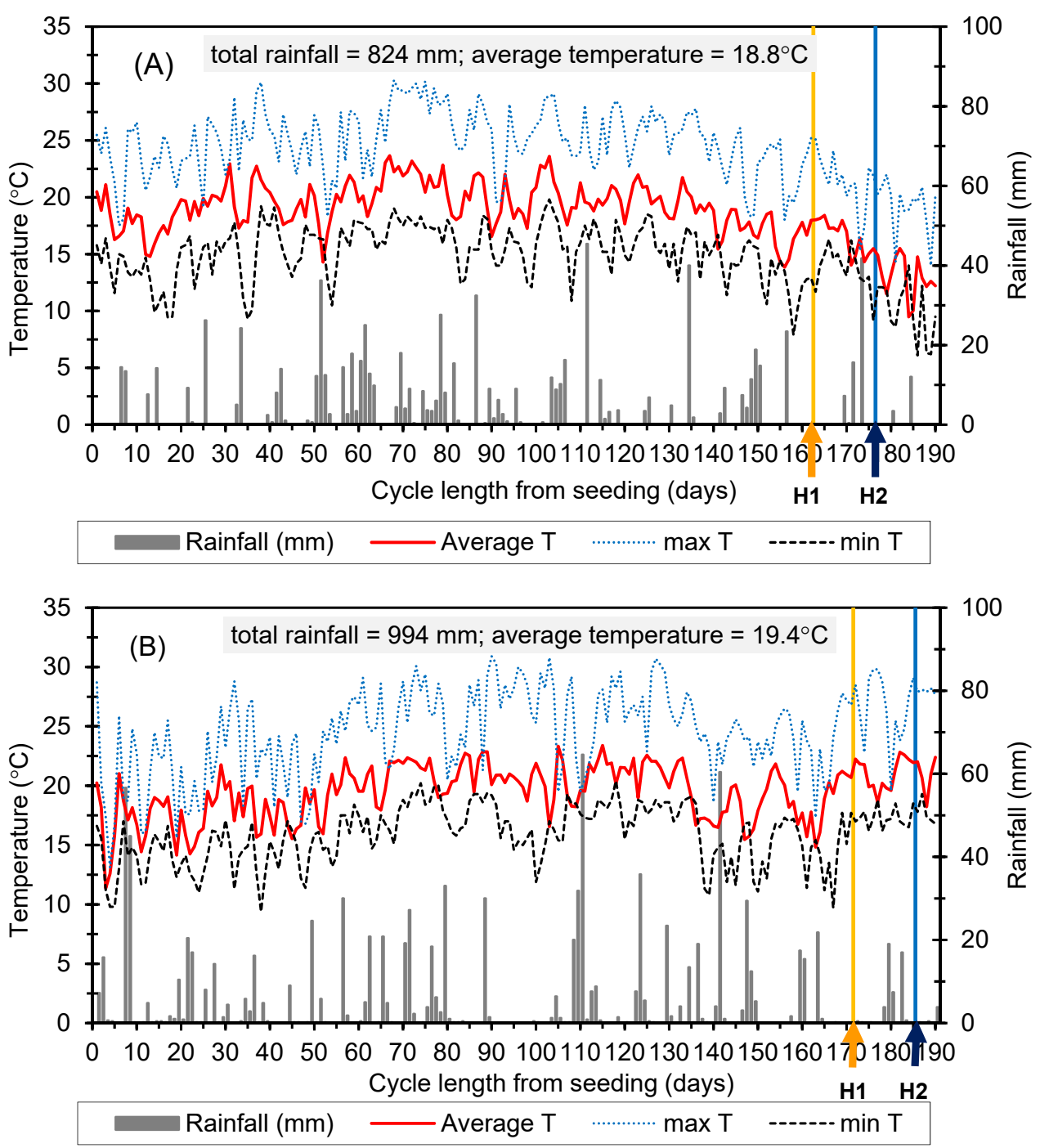

H1 is the harvest date for hybrid P1630 and H2 for P30F53, which are indicated with arrows.

Figure 1 - Temperatures (maximum, minimum and average) and rainfall diary of maize cycles from seeding to harvest, during 2014/ 15 (A) and 2015/16 (B) growing seasons.

The experimental design used was of randomized blocks arranged in split-split plots with three replications per treatment. In the main plot, two simple maize hybrids with contrasting growth cycles were assessed, namely, P1630 (very early maturing variety) and P30F53 (early maturing variety). These two hybrids were the most cultivated species in southern Brazil during the 2013/2014 growing season (Pioneer, 2016). At the split plots, four different nitrogen rates used as side-dress were tested, equivalent to $0,0.5,1$ and 1.5 times the required dosage to obtain $21,000 \mathrm{~kg} \mathrm{ha}^{-1}$ of yield, according to the recommendations of the Commission of Soil Chemistry and Fertility - RS/SC (CQFS-RS/SC, 2004). Quantitatively, such rates were equivalent to the application of $0,150,300$ and $450 \mathrm{~kg}$ of $\mathrm{N} \mathrm{ha}^{-1}$. The $\mathrm{N}$ (urea) doses were divided equally for application at three different stages, when maize was at the V4, V8 and V12 stages of Ritchie et al. scale (1993). In the split-split plots, the presence or absence of trinexapac-ethyl growth regulator was tested. Each split-plot consisted of four rows with seven meters in length, spaced $0.7 \mathrm{~m}$. All assessments were made in the two central rows, eliminating $0.5 \mathrm{~m}$ at the end of each row, resulting in a net area of $8.4 \mathrm{~m}^{2}$.

The experiments were implemented using hand seeding and no-tillage system (over Avena strigosa and Vicia sativa straw, desiccated with glyphosate and applied four weeks before seeding), planting three seeds per furrow on the $1^{\text {st }}$ Nov, 2014 and 15 Oct, 2015. Maintenance fertilization was performed at the seeding day, with the aim of producing $21,000 \mathrm{~kg} \mathrm{ha}^{-1}$ of grains, as 
recommended by the Commission for Soil Chemistry and Fertility - RS/SC (CQFS-RS/SC, 2004). Thirty $\mathrm{kg} \mathrm{ha}^{-1}$ of $\mathrm{N}$ (urea), $295 \mathrm{~kg} \mathrm{ha}^{-1}$ of $\mathrm{P}_{2} \mathrm{O}_{5}$ (triple superphosphate) and $170 \mathrm{~kg} \mathrm{ha}^{-1}$ of $\mathrm{K}_{2} \mathrm{O}$ (potassium chloride) were applied. The fertilizers were applied on the surface near the planting rows. When the plants reached stage V3, they were thinned to reach a population of 90,000 plants ha ${ }^{-1}$. This plants density was adopted for being above the one indicated by the maize breeder, for both hybrids, aiming to expose the crop to greater intraspecific competition, and a $\mathrm{N}$ dose 1.5 times higher than the recommended level to increase predisposition to occurrence of lodging or stems breaking. Side-dress nitrogen fertilization was done according to the phenology, as follows: V4 (Nov 8, 2014 and Nov 14, 2015), V8 (Nov 26, 2014 and Dec 1st 2015) and V12 (Dec 16, 2014 and Dec 17, 2015). Pests, diseases and weeds were controlled chemically in order not to interfere with the crop agronomic performance.

The trinexapac-ethyl growth regulator was applied twice, when the plants reached stage V5 (Nov 14, 2014 and Nov 17, 2015) and V10 (Dec 4, 2014 and Dec 9, 2015), using the commercial product Moddus ${ }^{\circledR}$, at the rate of $150 \mathrm{~g}$ a.i. ha ${ }^{-1}$ at each application These plant stages were chosen because it is when internodes on the maize stalk expand. Spraying was directed to the upper leaves of the plants using a $\mathrm{CO}_{2}$ pressurized backpack sprayer, calibrated to a total liquid volume equivalent to $200 \mathrm{~L} \mathrm{ha}^{-1}$.

When the crop was at stage R3 (milky grain), plant height, height of insertion of the first ear and height of the ear up to the end of tassel were measured using a millimeter-graded tape. The upper internodes length was determined by measuring the distance between the stem internode where the ear was inserted and the end of the tassel. Measurement of the stem diameter was taken at the harvest day using a digital caliper and the median third of the second internode from the plant base by the mean values obtained for the smallest and largest diameter of the stalks. These variables were assessed in five plants with phenological uniformity, previously identified at stage V4 at each split plot.

The percentage of lodged and broken stems was determined at harvest. It was considered as lodged plants when the stalk formed an angle below $45^{\circ}$ in relation to the ground, and as broken plants the ones which showed a break of the stalk below the maize ear. The agronomic efficiency of nitrogen was determined according to the method proposed by Fageria and Baligar (2005), calculated by the equation, expressed in $\mathrm{kg} \mathrm{kg}^{-1}$,

$$
A E=(G Y w f-G Y w f) /(Q N a)
$$

where $A E$ is the agronomic efficiency; $G Y w F$, grains yield achieved with nitrogenous fertilizer; $G Y w o F$, grains yield without nitrogen fertilization; and $Q N a$, quantity of nitrogen applied (in kg).

Harvesting was made on Apr 11, 2015 and Apr 2, 2016 for the hybrid P1630 and Apr 25, 2015 and Apr 16, 2016 for the hybrid P30F53. The ears were hand harvested and then threshed with a stationary thresher. Grain yield and 1000-grain weight were expressed at the standard moisture of $130 \mathrm{~g} \mathrm{~kg}^{-1}$.

Data were subjected to analysis of variance, using the F-test at a probability level of $5 \%$ $(p<0.05)$. When the significance levels were attained, the means of the qualitative factors (hybrid and use of growth regulator) were compared by the Tukey's test, and the means of the quantitative factor (nitrogen rates) by polynomial regression analysis both at $5 \%$ probability level $(\mathrm{p}<0.05)$.

\section{RESULTS AND DISCUSSION}

In both growing seasons, plant height and ear insertion height were affected by the main effects of the maize hybrid and nitrogen rates (Table 1). The hybrid P1630, although having an earlier development, exhibited the highest height and lowest ear insertion compared to P30F53 (Table 2). This was due to the longer distance between the node of the ear and the tassel end of the very early maturing genotype (P1630), indicating that the upper internodes of the stalk are longer than those of P30F53 variety. Plant height, ear insertion height (Figure 2A, B) and upper internodes (Figure $3 \mathrm{~A}$ ) of both hybrids exhibited a quadratic increase as the $\mathrm{N}$ rates of side-dress fertilization increased. The highest increases of these variables were observed up to fertilizer doses of $150 \mathrm{~kg}$ de $\mathrm{N} \mathrm{ha}^{-1}$. 
Table 1 - Mean square values and significances according to the analysis of variance for the morphological and productive characteristics of maize, as a function of the main effects of hybrids, nitrogen rates, growth rate and interaction between factors (in rows) during the 2014/15 and 2015/16 growing seasons

\begin{tabular}{|c|c|c|c|c|c|c|c|}
\hline & $\mathrm{H}$ & NR & GR & HxNR & HxGR & NRxGR & HxNRxGR \\
\hline \multicolumn{8}{|c|}{$2014 / 2015$} \\
\hline EIH & $10525.7 * *$ & $1338.3^{* *}$ & $6.5^{\mathrm{ns}}$ & $358.5^{\mathrm{ns}}$ & $8.7^{\mathrm{ns}}$ & $112.8^{\mathrm{ns}}$ & $122.8^{\mathrm{ns}}$ \\
\hline PH & $1539.1 *$ & $2918.2 * *$ & $581.2 *$ & $116.4^{\mathrm{ns}}$ & $7.2^{\mathrm{ns}}$ & $190.0^{\mathrm{ns}}$ & $136.4^{\mathrm{ns}}$ \\
\hline DIS & $20114.6^{* *}$ & $315.1^{\mathrm{ns}}$ & $709.9^{* *}$ & $90.0^{\mathrm{ns}}$ & $31.7^{\mathrm{ns}}$ & $114.2^{\mathrm{ns}}$ & $3.6^{\mathrm{ns}}$ \\
\hline PLB & $1.3^{\mathrm{ns}}$ & $1.21^{\mathrm{ns}}$ & $0.5^{\mathrm{ns}}$ & $2.9^{\text {ns }}$ & $0.8^{\mathrm{ns}}$ & $0.2^{\text {ns }}$ & $0.5^{\mathrm{ns}}$ \\
\hline $\mathrm{SD}$ & $17.5^{* *}$ & $12.4 * *$ & $0.4^{\mathrm{ns}}$ & $1.7^{\mathrm{ns}}$ & $2.7^{*}$ & $0.4^{\mathrm{ns}}$ & $0.2^{\mathrm{ns}}$ \\
\hline NEP & $0.006^{\mathrm{ns}}$ & $0.100 * *$ & $<0.001^{\text {ns }}$ & $0.001^{\mathrm{ns}}$ & $<0.001^{\mathrm{ns}}$ & $0.002^{\mathrm{ns}}$ & $0.003^{\mathrm{ns}}$ \\
\hline NGE & $871.3^{\mathrm{ns}}$ & $101736.5^{* *}$ & $1717.2^{\text {ns }}$ & $637.9^{\mathrm{ns}}$ & $1660.3^{\text {ns }}$ & $1204.2^{\text {ns }}$ & $400.6^{\mathrm{ns}}$ \\
\hline TGW & $34604.3 * *$ & $7200.7 * *$ & $1232.2 * *$ & $351.6^{\mathrm{ns}}$ & $67.7^{\mathrm{ns}}$ & $382.4^{\mathrm{ns}}$ & $407.7^{\mathrm{ns}}$ \\
\hline GY & $34821242 * *$ & $213213672 * *$ & $7956851^{*}$ & $1036314^{\mathrm{ns}}$ & $1480870^{\text {ns }}$ & $1145273^{\text {ns }}$ & $546775.0^{\mathrm{ns}}$ \\
\hline $\mathrm{AE}$ & $150.4^{\mathrm{ns}}$ & $5188.5^{* *}$ & $124.3^{\mathrm{ns}}$ & $51.9^{\mathrm{ns}}$ & $6.9^{\mathrm{ns}}$ & $34.8^{\text {ns }}$ & $7.5^{\mathrm{ns}}$ \\
\hline \multicolumn{8}{|c|}{$2015 / 2016$} \\
\hline EIH & $13061.4^{*}$ & $3057.0^{*}$ & $2310.2^{\mathrm{ns}}$ & $749.9^{\text {ns }}$ & $35.7^{\mathrm{ns}}$ & $821.2^{\mathrm{ns}}$ & $536.2^{\mathrm{ns}}$ \\
\hline $\mathrm{PH}$ & $2473.9 * *$ & $3017.4 * *$ & $0.07^{\mathrm{ns}}$ & $10.5^{\mathrm{ns}}$ & $103.8^{\mathrm{ns}}$ & $56.2^{\text {ns }}$ & $129.4^{\mathrm{ns}}$ \\
\hline DIS & $18267.6 * *$ & $201.5 * *$ & $358.6^{\mathrm{ns}}$ & $19.3^{\mathrm{ns}}$ & $161.3^{\mathrm{ns}}$ & $28.8^{\mathrm{ns}}$ & $130.0^{\mathrm{ns}}$ \\
\hline PLB & $12.9^{\mathrm{ns}}$ & $14.2 * *$ & $1.5^{\mathrm{ns}}$ & $5.9^{\mathrm{ns}}$ & $2.8^{\mathrm{ns}}$ & $1.3^{\mathrm{ns}}$ & $7.8^{\mathrm{ns}}$ \\
\hline SD & $72.9 * *$ & $20.4 * *$ & $0.1^{\mathrm{ns}}$ & $1.8 * *$ & $1.6^{\mathrm{ns}}$ & $1.8^{\mathrm{ns}}$ & $1.3^{\mathrm{ns}}$ \\
\hline NEP & $<0.001^{\mathrm{ns}}$ & $0.012 * *$ & $0.003^{\mathrm{ns}}$ & $0.019 * *$ & $<0.001^{\mathrm{ns}}$ & $<0.001^{\mathrm{ns}}$ & $0.002^{\mathrm{ns}}$ \\
\hline NGE & $14828.0^{*}$ & $51490.0 * *$ & $312.6^{\mathrm{ns}}$ & $2415.7^{\mathrm{ns}}$ & $2.1^{\mathrm{ns}}$ & $194.5^{\text {ns }}$ & $1721.7^{\mathrm{ns}}$ \\
\hline TGW & $18664.0 * *$ & $9609.3^{* *}$ & $753.4^{*}$ & $144.9^{\text {ns }}$ & $27.3^{\mathrm{ns}}$ & $133.7^{\mathrm{ns}}$ & $165.5^{\mathrm{ns}}$ \\
\hline GY & $4913280^{*}$ & $112792756^{* *}$ & $119900^{\mathrm{ns}}$ & $1009806^{\mathrm{ns}}$ & $488235^{\mathrm{ns}}$ & $311449^{\mathrm{ns}}$ & $1195086^{\mathrm{ns}}$ \\
\hline $\mathrm{AE}$ & $76.5^{\mathrm{ns}}$ & $2604.0 * *$ & $38.6^{\mathrm{ns}}$ & $15.3^{\mathrm{ns}}$ & $120.0^{*}$ & $16.5^{\mathrm{ns}}$ & $19.7^{\mathrm{ns}}$ \\
\hline
\end{tabular}

F-test; ** significant at $1 \%$ probability level $(\mathrm{p}<0.01)$; significant at $5 \%$ probability level $(0.01 \mathrm{~d} " 0.05)$; ns, non significant $(\mathrm{p}>0.05)$. Abbreviations: ear insertion height (EIH), plant height ( $\mathrm{PH})$, distance from the ear insertion node to tassel (DIS), percentage of lodged plants and broken stems (PLB), stem diameter (SD), number of ear per plant (NEP), number of grains per ear (NGE), 1000-grain weight (TGW), grains yield (GY), agronomic effciency of nitrogen use (AE), hybrids (H), nitrogen rate (NR), growth regulator (GR).

Table 2 - Plant height, ear insertion height, length of internodes above the ear, grains yield and 1000-grain weight of two maize hybrids on the mean value of four nitrogen rates, with and without growth regulator (trinexapac-ethyl), during the 2014/15 and 2015/16 growing seasons. Lages, SC

\begin{tabular}{|c|c|c|c|}
\hline \multirow{2}{*}{ Variable } & \multicolumn{2}{|c|}{ Hybrid } & \multirow{2}{*}{$\mathrm{CV}(\%)^{(1)}$} \\
\hline & $\mathrm{P} 1630$ & P30F53 & \\
\hline \multicolumn{4}{|c|}{$2014 / 15$} \\
\hline Plant height $(\mathrm{cm})$ & $258 a^{*}$ & $247 \mathrm{~b}$ & 5.66 \\
\hline Ear insertion height $(\mathrm{cm})$ & $122 \mathrm{~b}$ & $152 \mathrm{a}$ & 6.47 \\
\hline Length of internode above the ear ${ }^{(2)}(\mathrm{cm})$ & $136 \mathrm{a}$ & $95 \mathrm{~b}$ & 8.04 \\
\hline Grains yield $\left(\mathrm{kg} \mathrm{ha}^{-1}\right)$ & $11578 \mathrm{~b}$ & $13281 \mathrm{a}$ & 7.10 \\
\hline 1000 -grain weight $(\mathrm{g})$ & $326 \mathrm{~b}$ & $380 \mathrm{a}$ & 4.35 \\
\hline \multicolumn{4}{|c|}{$2015 / 16$} \\
\hline Plant height $(\mathrm{cm})$ & $264 \mathrm{a}$ & $250 \mathrm{~b}$ & 2.97 \\
\hline Ear insertion height $(\mathrm{cm})$ & $129 \mathrm{~b}$ & $162 \mathrm{a}$ & 19.77 \\
\hline Length of internodes above ear $(\mathrm{cm})$ & $135 \mathrm{a}$ & $96 \mathrm{~b}$ & 5.52 \\
\hline Grains yield $\left(\mathrm{kg} \mathrm{ha}^{-1}\right)$ & $12511 \mathrm{~b}$ & $13151 \mathrm{a}$ & 5.38 \\
\hline 1000-grain weight $(\mathrm{g})$ & $339 \mathrm{~b}$ & $379 \mathrm{a}$ & 1.70 \\
\hline
\end{tabular}

* Means followed by distinct lowercase letters in row differ from one another by the Tukey's test $(\mathrm{p}<0.05)$. Ns: Non significant differences between mean values in row ( $\mathrm{p}>0.05)$. ${ }^{(1)}$ Coefficient of variation. ${ }^{(2)}$ Distance between the ear insertion node to the tassel end. 

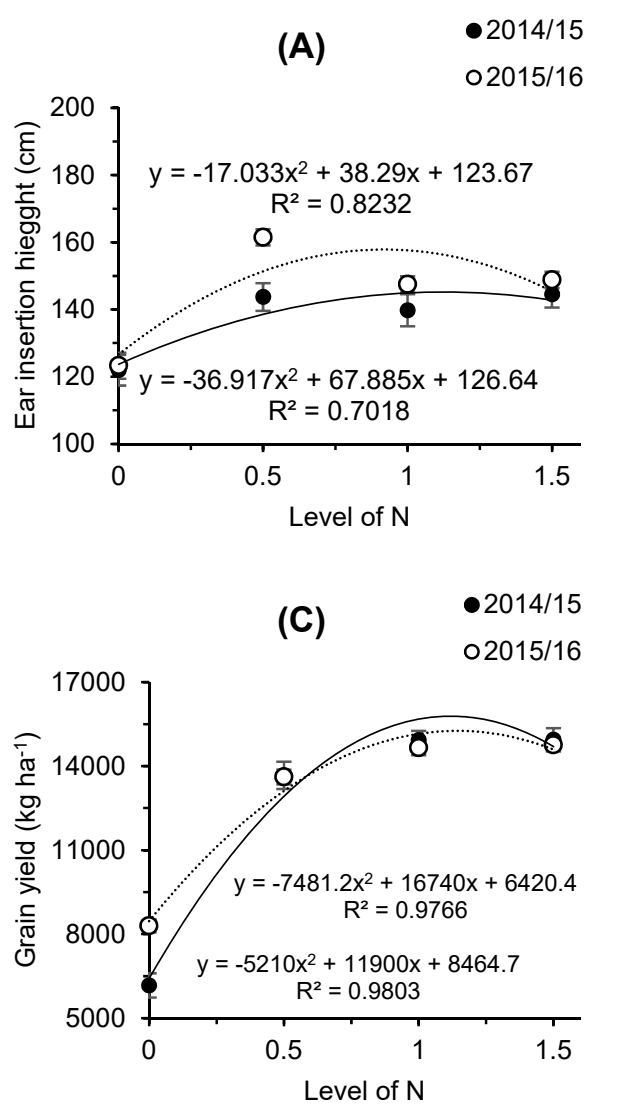

(B)

-2014/15

$02015 / 16$

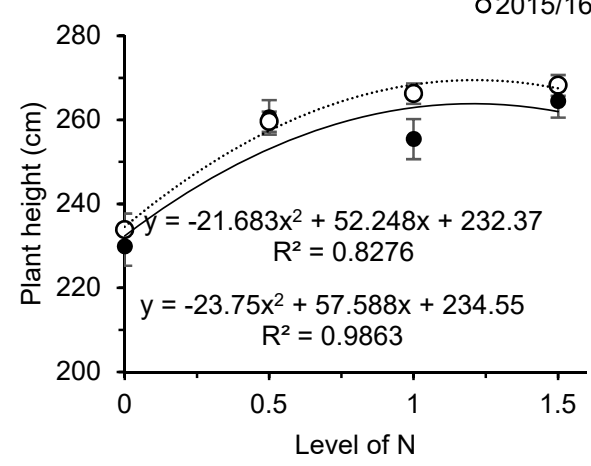

(D)

-2014/15

02015/16

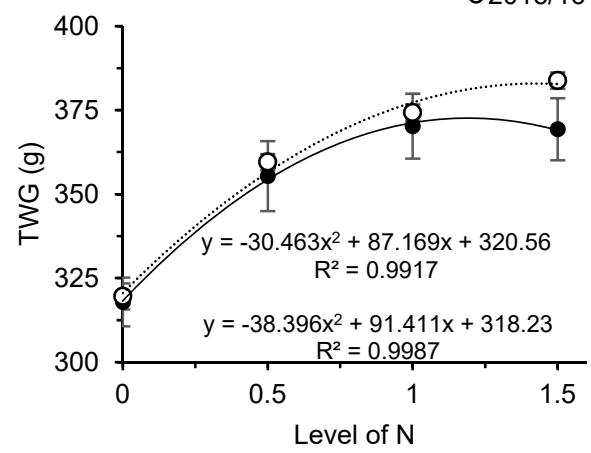

Rate 1.0 is equivalent to the application of $300 \mathrm{~kg} \mathrm{ha}^{-1}$ of $\mathrm{N} \mathrm{ha}^{-1}$. Bars represent standard errors of means.

Figure 2 - Height of ear insertion (A), plant height (B), grains yield (C) and 1000-grain weight (D) as a function of nitrogen application rates in the average of two hybrids, with and without the growth regulator trinexapac-ethyl, during 2014/15 and 2015/ 16 growing seasons. Lages, SC.

(A)

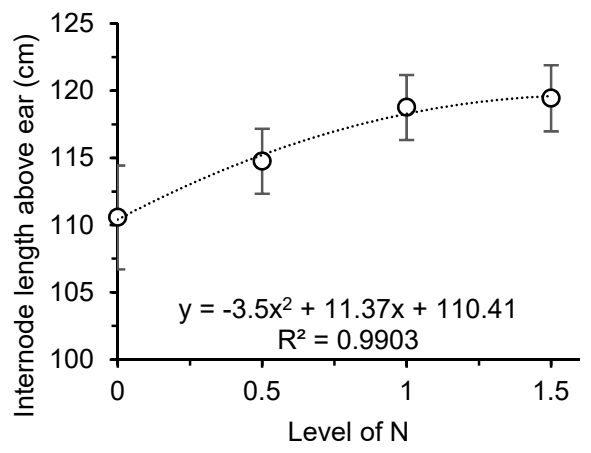

(B)

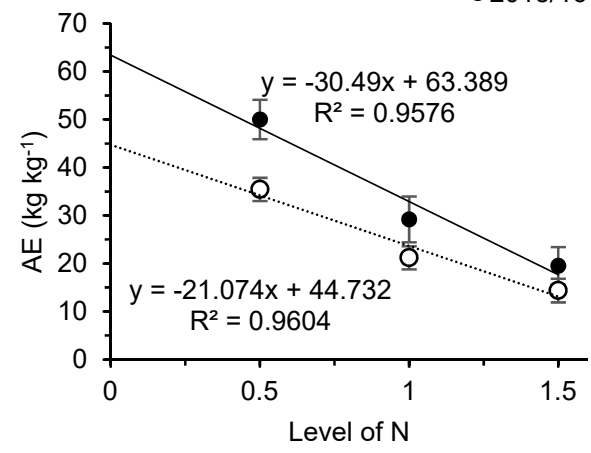

Rate1.0 is equivalent to the application of $300 \mathrm{~kg} \mathrm{ha}^{-1}$ of $\mathrm{N} \mathrm{ha}^{-1}$. Bars represent standard error of means.

Figure 3 - Internodes length above the uppermost ear in 2015/16 (A) and agronomic effciency of nitrogen use on maize in 2014/15 and 2015/16 growing seasons (B) as a function of different nitrogen rates, mean of two hybrids, with and without application of growth regulator trinexapac-ethyl. Lages, SC.

In 2014/15, the use of the growth regulator restricted the maize plants height by $7 \mathrm{~cm}$ in the mean heights of both hybrids and the four nitrogen rates assessed in the study, representing a decrease of approximately $2.7 \%$ for this variable (Table 3 ). The reduced plants height with the use of trinexapac-ethyl was also reported for maize by Fagherazzi et al. (2018), Leolato et al. (2017) and Pricinotto et al. (2015) in other plants of the Poaceae family, such as 
Table 3 - Plant height, length of internodes above the ear, grains yield and 1000-grain weight, with and without growth regulator trinexapac-ethyl, in the average of two hybrids and four nitrogen rates, during 2014/15 and 2015/16 growing seasons. Lages, SC

\begin{tabular}{|c|c|c|c|}
\hline \multirow{2}{*}{ Variable } & \multicolumn{2}{|c|}{ Trinexapac ethyl } & \multirow{2}{*}{ CV $(\%)^{(1)}$} \\
\hline & With & Without & \\
\hline \multicolumn{4}{|c|}{$2014 / 15$} \\
\hline Plant height $(\mathrm{cm})$ & $249 b^{*}$ & $256 \mathrm{a}$ & 3.65 \\
\hline Length of internodes above ear ${ }^{(2)}(\mathrm{cm})$ & $111 \mathrm{~b}$ & $119 \mathrm{a}$ & 6.11 \\
\hline Grains yield $\left(\mathrm{kg} \mathrm{ha}^{-1}\right)$ & $12022 \mathrm{~b}$ & $12837 \mathrm{a}$ & 8.84 \\
\hline 1000-grain weight $(\mathrm{g})$ & $348 \mathrm{~b}$ & $358 \mathrm{a}$ & 3.22 \\
\hline \multicolumn{4}{|c|}{$2015 / 16$} \\
\hline Plant height $(\mathrm{cm})$ & $257^{\mathrm{ns}}$ & 257 & 2.18 \\
\hline Length of internodes above ear $(\mathrm{cm})$ & $113 b$ & $119 \mathrm{a}$ & 8.15 \\
\hline Grains yield $\left(\mathrm{kg} \mathrm{ha}^{-1}\right)$ & $12780^{\mathrm{ns}}$ & 12880 & 5.68 \\
\hline 1000-grain weight $(\mathrm{g})$ & $355 \mathrm{~b}$ & $363 \mathrm{a}$ & 2.99 \\
\hline
\end{tabular}

* Means followed by distinct lowercase letters in rows differ from one each other by the Tukey's test $(\mathrm{p}<0.05)$. Ns: Non significant differences between mean values in row $(\mathrm{p}>0.05)$. ${ }^{(1)}$ Coefficient of variation. (2) Distance between the ear insertion node to the tassel end.

wheat (Espindula et al., 2010; Marco Junior et al., 2013; Chavarria et al., 2015), oats (Hawerroth et al., 2015) and sorghum (May et al., 2013). On the other hand, in the second crop year, the plants exhibited the same height, with and without application of growth regulator.

In both 2014/15 and 2015/16 crop years, there was a significant effect of application of growth regulator on the length between the ear insertion node and the tassel end (Table 1). Trinexapacethyl reduced this variable by 8 and $6 \mathrm{~cm}$ in the first and second growing seasons, respectively (Table 3). These results suggest that there was a reduction in the upper internodes length with application of this product, corroborating information obtained by Leolato et al. (2017), who applied trinexapac-ethyl at stages V5 and V10, and by Fagherazzi et al. (2018), who applied trinexapacethyl at stages V2 to V8 - studies that were carried out in the same region. But for wheat, Espindula et al. (2010) and Chavarria et al. (2015) observed a greater restrictive effect of this growth regulator on the internodes at the stem base. The diverse effect of the product on cereal crops may be associated with the maturity stage and the number of application times. For wheat, application is made integrally between elongation of the first and the second internode (Zagonel and Ferreira, 2013). In the present work, trinexapac-ethyl was applied twice at stages V5 and V10. It is worth mentioning that in maize there is no great variation in the internodes length along the stem, which is a fact observed for Triticum aestivum and Avena stativa; even so, application on these crops had a greater effect on the apical internodes of the plant, which could not achieve complete elongation (Hawerroth et al., 2015; Stefen et al., 2017; Fagherazzi et al., 2018).

The percentages of lodged and broken plants were low and ranged from 0.4 and 1.5, not significantly influenced by the hybrids, nitrogen rates and application of the growth regulator in two years of study (Table 1). High $\mathrm{N}$ rates may impair the plant ability to remain standing due to the stimulus during the vegetative growth by increasing the plant height, height of ears insertion and use of carbon skeletons for the production of amino acids and proteins. This makes the stem less fibrous, favoring its breaking and lodging (Sangoi et al., 2016). This trend was not observed in the present work because the use of 150 or $350 \mathrm{~kg} \mathrm{ha}^{-1}$ of $\mathrm{N}$, compared to the rate of $300 \mathrm{~kg} \mathrm{ha}^{-1}$ of $\mathrm{N}$, had little effect $( \pm 10 \mathrm{~cm})$ on the plant height and ear insertion height (Figure 2A, B) and did not affect the percentage of lodged and broken plants, irrespective of application of the growth regulator.

In 2014/15, the increased stalk diameter between the hybrids was distinct with application of growth regulator (Table 4). The stalk diameter of hybrid P1630 was smaller with application of trinexapac-ethyl, while hybrid P30F53 was not affected by the use of the product. Different increase and decrease responses on the stalk diameter with the use of trinexapac-ethyl were also observed by Zagonel and Ferreira (2013), Pricinotto et al. (2015), Leolato et al. (2017) and Fagherazzi et al. (2018), indicating that the behavior of this variable is little affected with application of trinexapacethyl. Although the stalk diameter is vital for resistance to lodging in wheat, Zagonel and Ferreira (2013) did not achieve consistent responses for this variable with application of growth regulator 
in different cultivars. In both crop years, the increased $\mathrm{N}$ rate caused a quadratic increase in the stalk diameter, and the hybrid P30F53 showed higher values for this variable than P1630 (Figure 4, Table 4). It should be pointed out that the diameter of the internodes was measured at the plant base, internodes that were not affected in their extension by trinexapac-ethyl. Thus, the stalk diameter between the hybrids was different with application of the growth regulator (Table 4). The stalk diameter of hybrid P1630 was smaller with application of trinexapac-ethyl, while hybrid P30F53 did not change with the use of this product. Thus, a hypothesis could be made, that the internodes positioned above the ear and which were smaller would be the ones that had their respective diameters changed by the growth regulator. Some evidences indicate that, in maize, the position of the internode on the stalk that will be affected by the exogenous application of growth regulator is dependent on the ear differentiation, i.e., if the ear is not differentiated, the affected internodes will be those below the ear, and if the ear is already differentiated, the affected internodes will be positioned above this organ (Spitzer et al., 2015).

Table 4 - Stem diameter and agronomic efficiency of nitrogen in two maize hybrids, with and without application of growth regulator trinexapac-ethyl, in the average of four nitrogen rates, during 2014/15 and 2015/16 growing seasons. Lages, SC

\begin{tabular}{|c|c|c|c|}
\hline \multirow{2}{*}{ Hybrid } & \multicolumn{2}{|c|}{ Trinexapac ethyl } & \multirow{2}{*}{$\mathrm{CV}(\%)^{(1)}$} \\
\hline & With & Without & \\
\hline & \multicolumn{2}{|c|}{ Stem diameter $(\mathrm{mm})$} & \multirow{4}{*}{2.7} \\
\hline & \multicolumn{2}{|c|}{$2014 / 15$} & \\
\hline P1630 & $21.3 \mathrm{~b} \mathrm{~B}^{*}$ & 21.9 a B & \\
\hline \multirow[t]{2}{*}{ P30F53 } & $23.0 \mathrm{a} \mathrm{A}$ & $22.7 \mathrm{a} \mathrm{A}$ & \\
\hline & \multicolumn{2}{|c|}{$2015 / 16$} & \\
\hline P1630 & $21.0 \mathrm{~B}$ & $20.7 \mathrm{~B}$ & \multirow{2}{*}{4.2} \\
\hline \multirow[t]{3}{*}{ P30F53 } & $23.1 \mathrm{~A}$ & $23.5 \mathrm{~A}$ & \\
\hline & \multicolumn{2}{|c|}{ Agronomic efficiency $\left(\mathrm{kg} \mathrm{kg}^{-1}\right)$} & \multirow{4}{*}{38.7} \\
\hline & \multicolumn{2}{|c|}{$2014 / 15$} & \\
\hline P1630 & $20.9^{\mathrm{ns}}$ & 24.8 & \\
\hline \multirow[t]{2}{*}{ P30F53 } & 25.2 & 27.6 & \\
\hline & \multicolumn{2}{|c|}{$2015 / 16$} & \\
\hline P1630 & $14.0 \mathrm{~b} \mathrm{~B}$ & 18.9 a A & \multirow{2}{*}{23.6} \\
\hline P30F53 & 19.6 a A & $18.3 \mathrm{a} A$ & \\
\hline
\end{tabular}

* Means followed by distinct lowercase letters in rows and uppercase in columns differ significantly by the Tukey's test at $5 \%$ significance level. Ns: Non significant mean differences ${ }^{(1)}$ Coefficient of variation.

(A)

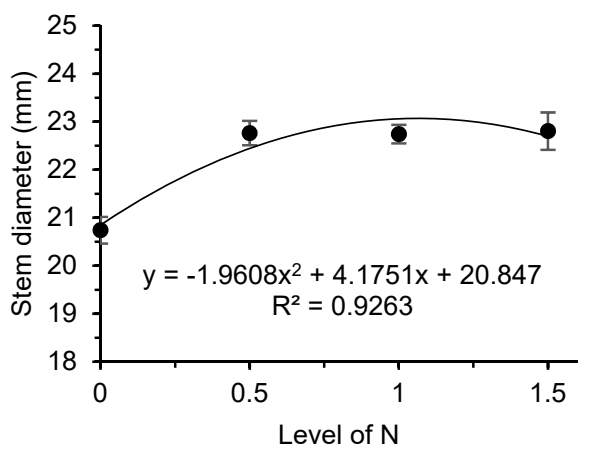

(B)

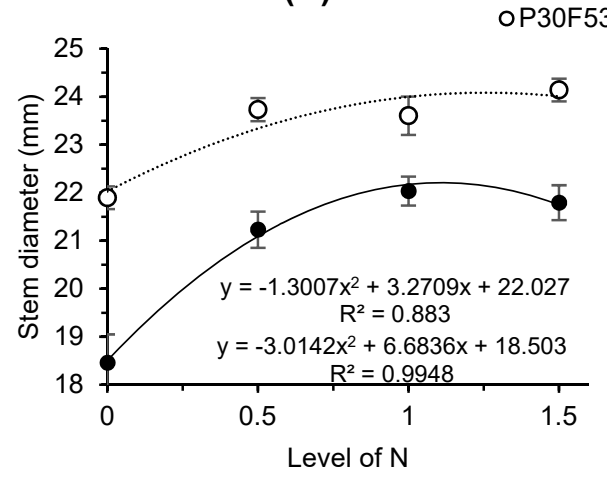

Rate1.0 is equivalent to the application of $300 \mathrm{~kg} \mathrm{ha}^{-1}$ of $\mathrm{N} \mathrm{ha}^{-1}$. Bars represent standard error of means.

Figure 4 - Stem diameter of maize plant as a function of different nitrogen rates, in the average of two hybrids, with and without application of growth regulator trinexapac-ethyl in 2014/15 (A), and as a function of two hybrids, with and without growth regulator trinexapac-ethyl in the 2015/16 growing seasons (B). Lages, SC. 
In the first growing season, with application of the growth regulator, the maize grains yield decreased by $6.3 \%$ in the average of both hybrids and four different nitrogen rates (Table 3). In the second growing season, there was no significant effect of the product on grains yield. Such magnitudes of response follow the tendencies reported by Fagherazzi et al. (2018) and Pricinotto et al. (2015) relating to maize grains yield with application of trinexapac-ethyl.

There was a quadratic response of grains yield with increased sidedressing nitrogen application rates (Figure 2C). The maximum theoretical grain yields obtained from the first derivative of the quadratic functions adjusted to data were $15,784 \mathrm{~kg} \mathrm{ha}^{-1}$ in $2014 / 15$ and $15,257 \mathrm{~kg} \mathrm{ha}^{-1}$ in $2015 / 16$. In both crop years, the $\mathrm{N}$ rate of $330 \mathrm{~kg} \mathrm{ha}^{-1}$ provided the maximum grains yield and was equivalent to 1.1 times the amount of $\mathrm{N}$ recommended by the Southern Brazilian Commission on Soil Chemistry and Fertility (CQFSRS/SC, 2004) to reach the production ceiling limit of $21,000 \mathrm{~kg} \mathrm{ha}^{-1}$ (in this case, $330 \mathrm{~kg}$ of N ha-1). The hybrid P30F53 was $12.8 \%$ and 4.8\% more productive than hybrid P1630, in 2014/15 and 2015/16, respectively (Table 2).

Although maximum theoretical yields have been attained with application of $330 \mathrm{~kg}$ of $\mathrm{N} \mathrm{ha}^{-1}$, the real values of this variable, as described in Figure 2, show that applications higher than $150 \mathrm{~kg}$ of $\mathrm{N} \mathrm{ha}^{-1}$ were not conducive to substantial increases in grains yield. This shows that the response to the increased $\mathrm{N}$ rate was not significant, regardless of whether the growth regulator was applied or not. Two factors contributed to this behavior. The first was the high content of organic matter $\left(60 \mathrm{~g} \mathrm{~kg}^{-1}\right)$ of Red Nitosol soil in which this study was conducted, which contributed to the $6,000 \mathrm{~kg} \mathrm{ha}^{-1}$ yield in the plot without application of nitrogen. The second factor was the ceiling production limits attained in the experiment. In both growing seasons studied, the grains yields did not exceed $16,000 \mathrm{~kg} \mathrm{ha}^{-1}$ and were lower than those expected for 300 and $450 \mathrm{~kg} \mathrm{ha}^{-1}$ of side-dress $\mathrm{N}$ application, respectively. The higher the maize yield, the higher the crop demand for nitrogen and its response to the application of mineral side-dress $\mathrm{N}$ rates (Sangoi et al., 2015).

In both crop years, the increased $\mathrm{N}$ rates provided a quadratic adjustment in 1000-grain weight (Figure 2D), and the hybrid P30F53 had heaven grains than P1630, which contributed to its higher grains yield (Table 2). Application of trinexapac-ethyl reduced by $10 \mathrm{~g}$ and $8 \mathrm{~g}$ the 1000 grain weight, in the first and second growing season, respectively (Table 3). These results corroborated the ones obtained by Pricinotto et al. (2015) and Leolato et al. (2017) with maize crop and disagree with data reported by Zagonel and Ferreira (2013), who found heavier wheat grains produced with application of growth regulator.

The decreased 1000-grain weight with the use of trinexapac-ethyl may result from anatomic and morphological effects of the product on maize. Anatomically, the temporary reduction of endogenous gibberellin levels may have changed the meristematic cambial cells activity. Higher auxin concentration favors formation of xylem vessels, and higher gibberellin levels favor production of phloem vessels (Aloni, 1987). Other potential consequence may be an accelerated elongation of metaxylem, epidermal and cortical cells, with consequent increase of vacuolization of cells (Spitzer et al., 2015). Thus, it is possible that more differentiation of the xylem vessels to the detriment of the phloem vessels may likely have occurred in the plants that were subjected to product application. This may have reduced the quantity of vessels that account for the translocation of photoassimilates to the maize ear, resulting in the formation of lighter grains. Morphologically, the upper internodes shortening may have impaired interception of solar radiation of above-ear leaves. In addition, shorter internodes have less amount of reserves to direct to the grains after flowering (Fagherazzi et al., 2018).

The agronomic efficiency (AE) of nitrogen use was affected by the main effect of $\mathrm{N}$ rates in both growing seasons (Table 1). Efficiency ranged from 14 to $49 \mathrm{~kg}$ of grains produced per $\mathrm{kg}$ of $\mathrm{N}$ as side-dress, depending on the crop year and $\mathrm{N}$ rate (Figure 3B). AE decreased linearly according to increasing rates of $175(0.5)$ to $450 \mathrm{~kg}$ of N ha-1, with decreased values of 30 and $21 \mathrm{~kg} \mathrm{~kg}^{-1}$ in 2014/ 15 and 2015/16, respectively. However, the values found in this work were lower than the ones reported by Sangoi et al. (2015), who obtained AEs of 95 and $55 \mathrm{~kg} \mathrm{~kg}^{-1}$ with the rates of 150 and $300 \mathrm{~kg}$ of $\mathrm{N} \mathrm{ha}^{-1}$. The increasing $\mathrm{N}$ rates diminished the plant $\mathrm{AE}$ in using it in grains production (Mota et al., 2015; Vargas et al., 2015).

Although previous studies reported positive results for grains yield with application of trinexapac-ethyl on wheat crops (Penckowski et al., 2010; Espindula et al., 2010), with maize the 
reduced percentage of lodged and broken stems, the low response of the hybrids to $\mathrm{N}$ rates higher than $150 \mathrm{~kg} \mathrm{ha}^{-1}$ and production ceiling limits lower than $16,000 \mathrm{~kg} \mathrm{ha}^{-1}$ likely attenuated the beneficial effect of growth regulator on the maize agronomic performance. Thus, the beneficial effects of trinexapac-ethyl on reducing the maize vegetative growth, diminishing the percentage of lodged plants, increasing the grains yield response to increased nitrogen rates and on the efficiency of nitrogen use to grains production were not confirmed in both years of this study, and, therefore, this hypothesis was rejected.

In short, the growth regulator trinexapac-ethyl does not affect the grains yield response of maize to nitrogen side-dress rates, irrespective of the hybrid cycle. Application of trinexapacethyl does not affect the percentage of lodged and broken plants and does not increase the maize agronomic efficiency due with nitrogen use.

\section{ACKNOWLEDGEMENTS}

The authors wish to thank CNPq for the productivity scholarship granted to the first and change for third authors of the study; UNIEDU/Fumdes for the scholarship granted to the second author of the study; FAPESC/PAP/UDESC for the support to the research.

\section{REFERENCES}

Aloni R. Differentiation of vascular tissues. Ann Rev Plant Physiol. 1987;38:179-204.

Chavarria G, Rosa WP, Hoffmann L, Durigon MR. Regulador de crescimento em plantas de trigo: reflexos sobre o desenvolvimento vegetativo, rendimento e qualidade de grãos. Rev Ceres. 2015;62(6):583-88

Comissão de Química e Fertilidade do Solo-CQFSRS/SC. Manual de adubação e calagem para os estados do Rio Grande do Sul e Santa Catarina. Porto Alegre: Sociedade Brasileira de Ciência do Solo/Núcleo Regional Sul; 2004.

Duete RRC, Muraoka T, Silva EC, Trivelin PCO, Ambrosano EJ. Manejo da adubação nitrogenada e utilização do nitrogênio (15 N) pelo milho em latossolo vermelho. Rev Bras Cienc Solo. 2008;32(1):161-71.

Empresa Brasileira de Pesquisa Agropecuária - Embrapa. Sistema brasileiro de classificação de solos. 2a .ed. Brasília, DF: Centro Nacional de Pesquisa de Solos; 2006.

Espíndula MC, Rocha VS, Souza LT, Souza MA, Grossi JAS. Efeitos de reguladores de crescimento na elongação do colmo de trigo. Acta Sci Agron. 2010;32(1):109-16.

Fageria NK, Baligar VC. Enhancing nitrogen use efficiency in crop plants. Adv Agron. 2005;88:97-185.

Fagherazzi MM, Souza CA, Casa RT, Coelho CMM. Supraoptimal nitrogen sidedressing on morpho-agronomic traits of maize. Rev Cienc Agrovet. 2016;15:74-9.

Fagherazzi MM, Souza CA, Stefen DLV, Zanesco PR, Junkes GV, Coelho CMM, et al. Phenological sensitivity of two maize cultivars to trinexapac-ethyl. Planta Daninha. 2018;36:e018154739.

Goes RJ, Goes RJ, Rodrigues RAF, Takasu AT, Arf O. Características Agronômicas e produtividade do milho sob fontes e doses de nitrogênio em cobertura de inverno. Rev Bras Milho Sorgo. 2013;12(3):250-59.

Hawerroth MC, Silva JAG, Oliveira AC, Luche HS, Zimmer CM, Hawerroth FJ, ET al. Redução do acamamento em aveia-branca com uso do regulador de crescimento etil-trinexapac. Pesq Agropec Bras. 2015;50:115-25.

Kappes C, Arf O, Arf MV, Gitti DC, Alcalde AM. Uso de regulador de crescimento no desenvolvimento e produção de crotalária. Pesq Agropec Trop. 2011;41(4):508-18.

Leolato L, Sangoi L, Durli MM, Panison F, Voss R. Growth regulator and maize response to the increase in plant density. Pesq Agropec Bras. 2017;52(11):997-1005.

Marco Junior J, Correa D, Nakai EH. Efeito do regulador de crescimento trinexapac-ethyl na produtividade de trigo. Acta Iguazu, 2013;2:14-9. 
May A, Magalhães PC, Abreu MC, Parrella NNLD, Campanha MM, Silva AF, Schaffert RE, Parrella RAC. Fito-hormônios no desenvolvimento vegetativo e germinação das sementes de sorgo sacarino. Rev Bras Milho Sorgo. 2013;12:33-43.

Mota MR, Sangoi L, Schenatto DE, Giordani W, Boniatti CM, Dall'Igna L. Fontes estabilizadas de nitrogênio como alternativa para aumentar o rendimento de grãos e a eficiência de uso do nitrogênio pelo milho. Rev Bras Cienc Solo. 2015;39:512-22.

Mundstock CM, Silva PRF. Manejo da cultura do milho para altos rendimentos de grãos. Porto Alegre: Evangraf; 2005.

Penckowski LH, Zagonel J, Fernandes EC. Qualidade industrial do trigo em função do trinexapac-ethyl e doses de nitrogênio. Cienc Agrotec. 2010;34:1492-9.

Pioneer. Ficha dos produtos - híbridos de milho.2016. [acessado em: 09 abr. 2018]. Disponível em: http:// www.pioneersementes.com.br/milho/central-de-produtos/busca-de-produtos?cat=Milho.

Pricinotto LF, Zucareli C, Fonseca ICB, Oliveira MA, Ferreira AS, Spolao LT. Trinexapac-ethyl in the vegetative and reproductive performance of corn. Afr J Agric Res. 2015;10(4):1735-42.

Ritchie SW, Hanway JJ, Benson GO. How a corn plant develops. Ames: Iowa State University of Science and Technology; 1993. (Special report, 48).

Sangoi L, Silva LMM, Mota MR, Panison F, Schmitt A, Souza NM. Desempenho agronômico do milho em razão do tratamento de sementes com Azospirillum sp e da aplicação de doses de nitrogênio mineral. Rev Bras Cienc Solo. 2015;39(4):1141-50.

Sangoi L, Silva PRF, Pagliarini N. Estratégias de manejo da adubação nitrogenada em milho na região sul do Brasil. Lages: Graphel; 2016. 119 p.

Santos MM, Galvão JCC, Vaz de Melo A, Adriano RC, Fidelis RR, Corrêa MLP. Efeito da fonte de nitrogênio e da época de aplicação na cultura do milho, em plantio direto, com espaçamento reduzido. Rev Bras Milho Sorgo. 2011;10(1):29-37.

Scherer EE. Calagem e adubação da cultura do milho. In: Wordell Filho JÁ, Elias HT. A Cultura do milho em Santa Catarina. $2^{\text {a }}$.ed. Florianópolis: 2012. p.7-45.

Spitzer T, Míša P, Bílovský J, Kazda J. Management of maize stand height using growth regulators. Plant Prot Sci. 2015;51(4):223-30.

Stefen DLV, Souza CA, Coelho CMM. pH of water and tank mixture comprising growth regulator and agrochemicals in wheat. J Exp Agric Inter. 2017;19(4):1-11.

Vargas VP, Sangoi L, Ernani PR, Picoli Jr GJ, Cantarella H. Maize leaf phytotoxicity and grain yield are affected by nitrogen source and application method. Agronomy J. 2015;107(2):671-9.

Zagonel J, Ferreira C. Doses e épocas de aplicação de regulador de crescimento em híbridos de milho. Planta Daninha. 2013;31(2):395-402.

Zhang Q, Zhang L, Evers J, van derWerf W, Zhang W, Duan L. Maize yield and quality in response to plant density and application of a novel plant growth regulator. Field Crops Res. 2014;164:82-9. 